\title{
Parasitus fimetorum and Macrocheles muscaedomesticae (Acarina:Parasitidae, Macrochelidae) as Natural Predators of the Root Knot Nematode, Meloidogyne javanica
} Treub

\author{
Hany Mohamed Heikal
}

\begin{abstract}
The potential use of two predacious mites, Parasitus fimetorum (Berlese 1904) and Macrocheles muscaedomesticae (Scopoli 1972), for controlling the root knot nematode, Meloidogyne javanica Treub 1885 was evaluated under laboratory and semi-field conditions. Obtained results revealed that the 2 predators significantly reduced the root knot nematode numbers. In addition, the highest reduction percentage (57.24\%) in nematode juveniles was recorded at the treatment of (1000 nematode +10 mites). For M. muscaedomesticae, the highest mortality percentage (50.83\%) in nematode juveniles was recorded at the treatment of (1000 nematode +50 mites), followed by (1000 nematodes +20 mites) 48.88\%, while the treatment of (1000 nematode +10 mites) gave (47.13\%). The combination of the 2 mite species (1000 nematodes +50 mites/species) caused the highest mortality percentages in nematode juveniles (69.29\%), followed by (1000 nematodes + 20 mite/species) $50.51 \%$ and the treatment of (1000 nematode +10 mite/species) (37.66\%). At the pot experiments, the highest overall mortality percentage in $M$. javanica juveniles was recorded at the treatment of $P$. fimetorum $+M$. muscaedomesticae giving (57.07\%), followed by the treatment of $P$. fimetorum (39.17\%), and then, by M. muscaedomesticae alone that recorded only (17.47\%). In conclusion, predacious mites can be partially considered a control tool of the parasitic nematodes.
\end{abstract}

Keywords: Predaceous mites, Parasitus fimetorum, Macrocheles muscaedomesticae, Biological control, Plant parasitic nematodes

\section{Background}

The root knot nematode, Meloidogyne javanica (Treub 1885), is one of the most serious pests, attacking large numbers of field, vegetable, and fruit plants in Egypt. It can be found in all types of soils and cultivated regions of Egypt. The use of chemical compounds for the control of nematodes is costly and negatively affecting the environment as well as human and animal health. Meanwhile, nematodes have a diverse range of natural

Correspondence: hanyheikal61@yahoo.com

Economic Entomology and Agricultural Zoology Department, Faculty of Agriculture, Menoufia University, Shebin El-Kom, Egypt enemies. Therefore, scientists are constantly exploring other biological control methods, rather than the use of chemical compounds.

Biological control of plant-parasitic nematode using predatory mites has been explored in several countries, especially in protected crops (Carrillo et al. 2015). Cosmopolitan mites of the families Laelapidae, Parasitidae, and Macrochelidae are free-living predators feeding on eggs and immature stages of other soil-inhabiting micro-arthropods and nematodes (Kazemi et al. 2013).

In Egypt, Taha et al. (1988) studied the effect of feeding Neocunaxoides andrei (Baker and Hoffmann) on the

\section{SpringerOpen}

๑ The Author(s). 2020 Open Access This article is licensed under a Creative Commons Attribution 4.0 International License, which permits use, sharing, adaptation, distribution and reproduction in any medium or format, as long as you give appropriate credit to the original author(s) and the source, provide a link to the Creative Commons licence, and indicate if changes were made. The images or other third party material in this article are included in the article's Creative Commons licence, unless indicated otherwise in a credit line to the material. If material is not included in the article's Creative Commons licence and your intended use is not permitted by statutory regulation or exceeds the permitted use, you will need to obtain permission directly from the copyright holder. To view a copy of this licence, visit http://creativecommons.org/licenses/by/4.0/. 
nematode, Panagrolimaus rigidus (Schneider 1866) Thorne 1937, on its developmental time and fecundity under laboratory conditions of $30{ }^{\circ} \mathrm{C}$ and $70 \% \mathrm{RH}$, and found that cunaxids are generalist predators because they feed on diverse prey, such as plant mites and other small arthropods and nematodes. In addition, Walter and Kaplan (1991) found that Coloscerius simplex Ewing colonized in greenhouse pot cultures fed on Meloidogyne spp. Mostafa et al. (1997) reported that Lasioseius dentatus Fox 1946 could develop on Meloidogyne javanica egg masses under laboratory conditions. El-Khateeb (1998) reared Coloscerius aegyptiacus Gomaa and ElKhateeb on the free living nematode, Rhabditis (Rhabditella) muscicola (Andrássy 1986), while Sholla Salwa (2000) reared Coloscerius buratus Den Heyer on the same previous nematode species. El-Hady Mona and ElNaggar (2001) studied the possibility of using the predacious laelapid mites, Hypoaspis bregetovae (Shereef and Afifi) and H. sardous (Canestrini 1884), as biological control agents of root knot nematode infesting sunflower plants. Maareg et al. (2005) evaluated the potentiality of 7 predacious mite species in feeding on the juveniles of Meloidogyne incognita and found that all the tested mites fed successfully on nematode stages except Cunaxa sp.

Although the acarina communities in Egyptian soils have not been widely studied, limited information is available on the mesostigmatid fauna. Owing to their numerical importance, the gamasid mites have received more attention than other soil Acari. The majority of these species are predators and found associated with small and immature stages of insects and nematodes inhabiting soil surface (El-Hady Mona and El-Naggar 2001; Mostafa et al. 2013; Carrillo et al. 2015). The natural enemies of plant parasitic nematodes include fungi, bacteria, and predacious invertebrates. These natural enemies of nematodes are often used in agricultural practices to suppress the populations of plant parasites (Kerry and Hominick 2002).

Mostafa et al. (2013) indicated that the type of tested nematode food and temperatures had a slight significant difference on the incubation period of uropodid mite, Uroobovilla krantzi Zaher and Afifi (both sexes), when fed on free living and plant parasitic nematodes. However, predacious mites and predacious nematodes can be essential control agents for certain nematodes (Yeates and Wardle 1996). Nevertheless, the practice of using predacious mites as control agents in agriculture is still limited.

The aim of the present work was to study the efficacy of the predatory mites, P. fimetorum (Berlese 1904) and M. muscaedomesticae (Scopoli 1972), against the root knot nematode, $M$. javanica, under laboratory and greenhouse conditions.

\section{Materials and methods}

Root knot nematode culture

Root knot nematode, $M$. javanica, juveniles were obtained from a pure culture reared at the Biological laboratory of Economic Entomology and Agricultural Zoology Department at the Faculty of Agriculture, Menoufia University, Egypt, by incubating egg masses in modified Baermann units. Newly hatched nematode juveniles were used for conducting experiments.

\section{Culture of Parasitus fimetorum}

The predatory mite, P. fimetorum, was collected from soil samples including leaf litter and farmyard manure and extracted by using modified Tullgren funnels for $72 \mathrm{~h}$ (Lindquist et al. 1979). The extracted predators were collected in distilled water and then transferred into plastic rearing units (Fouly 1996; Al-Rehiayni and Fouly 2005). Samples were taken from the experimental farm at the Faculty of Agriculture, Menoufia University, Egypt.

\section{Macrocheles muscaedomesticae culture}

Predatory mite specimens of $M$. muscaedomesticae were extracted, using Tullgren funnels from a house fly culture reared on artificial diet of $9 \mathrm{~g}$ powder milk and $5 \mathrm{~g}$ yeast dissolved in $100 \mathrm{ml}$ water, then added to $100 \mathrm{~g}$ fine bran (Wilkins and Khalequzzaman 1993). Glass cages $(60 \times 35 \times 40 \mathrm{~cm})$ were used for rearing the house fly under laboratory conditions $\left(25 \pm 5{ }^{\circ} \mathrm{C}, 60 \pm 5 \% \mathrm{RH}\right)$, and for 12:12 (L:D) (Palacios et al. 2009).

\section{Laboratory experiments}

To study the efficacy of both mite species and their potential in feeding on the root knot nematode juveniles, plastic Petri dishes $(5 \mathrm{~cm})$ were filled with $50 \mathrm{~g}$ pure fine sand to conduct different treatments:

1. First and second experiments were as follows:

- 1000 J2 M. javanica + 10, 20, and 50 ind. P. fimetorum or M. muscaedomesticae (15 dishes)

- $1000 \mathrm{~J} 2$ of $M$. javanica only (15 dishes) (control)

Treated dishes were randomized arranged and moistened with $30 \mathrm{ml}$ water every 5 days. Ten days later, 5 dishes from each treatment were examined for mites and nematodes by extraction, using the modified Baermann units and Tullgren funnels. Numbers of juveniles of root knot nematode and mite individuals were counted under dissecting stereomicroscope. The previous step was repeated 20 and 30 days after beginning.

2. Third experiment 
It consisted of 60 dishes as follows:

- 1000 J2 M. javanica + 10, 20, and 50 ind. P. fimetorum +10 ind. M. muscaedomesticae (15 dishes)

- 1000 J2 M. javanica only (15 dishes) (control)

\section{Greenhouse experiments}

Seventy plastic pots, each contained $2 \mathrm{~kg}$ of pure sand soil, were prepared for the following treatments:

- 5000 J2 M. javanica + 100 ind. P. fimetorum, $M$. muscaedomesticae, 100 ind. from each species together (10 pots each).

- 100 individuals of P. fimetorum and $M$. muscaedomesticae (10 pots)

- $5000 \mathrm{~J} 2$ of $M$. javanica only (control) (10 pots)

- Check treatment without any additives (10 pots)

Each pot was transplanted with two tomato seedlings ( 25 days old) and received the required populations of nematodes and mites as previously mentioned. Pots were randomized and arranged in the greenhouse at $23 \pm 2{ }^{\circ} \mathrm{C}$ and $65 \pm 5 \% \mathrm{RH}$. Pots were watered as required and received a standard nutritional solution. Thirty days later, the soils of 5 pots/ treatment were examined for nematode and mites, using the modified Baermann units and Tullgren funnels.

\section{Statistical analysis}

Data were analyzed using CoStat Soft Program 6.400 (CoStat version 6.400 Copyright $\odot$ (2008) and ANOVA test with LSD (5\%) and mean \pm SD. Mortality percentages were computed according to Abbott's formula (Abbott 1925).

\section{Results and discussion Laboratory experiments \\ Efficacy of Parasitus fimetorum against Meloidogyne javanica juveniles}

Statistical analysis of the obtained data indicated that there were significant differences in the numbers of nematode juveniles between the treatment with the nematode only (control) and each of the other treatments at the 3 periods of examination. Moreover, there were significant differences in nematodes' population among the 3 rates of the released predatory mite, $P$. fimetorum (Table 1 ). As shown in the table, there were significant differences between numbers of predatory mites, along experimental sampling, among the 3 ratios of release. Numbers of $P$. fimetorum were relatively low after 30 days at the treatment of (1000 nematodes +10 mites), while it increased at other treatments.

Mortality percentages in nematode juveniles indicated also that the highest reduction (57.24\%) was recorded at the treatment of (1000 nematodes +10 mites), followed by $(53.77 \%)$ at (1000 nematode +50 mites) and then $(50.87 \%)$ at the treatment of (1000 nematodes +20 mites).

The previous data revealed that there were significant differences in the activity of the predatory mite species towards the root knot nematode. The results are similar to those reported by Van de Bund (1972) with the predatory mite, Hypoaspis aculeifer (Canestrini 1884), which decreased the population of nematode $M$. javanica by $42 \%$.

Table 1 Mean numbers \pm SE of Meloidogyne javanica juveniles (M.) and P. fimetorum mite $(P$.$) extracted from different treatments$ and mortality percentages under laboratory conditions

\begin{tabular}{|c|c|c|c|}
\hline \multirow[t]{2}{*}{ Treatments } & \multicolumn{3}{|c|}{ Mean numbers \pm SE of $M$. javanica juveniles (days post-treatments) } \\
\hline & 10 & 20 & 30 \\
\hline M. + P. $(1000: 10)$ & $825.33 \pm 36.74 b$ & $212.33 \pm 1.45 c$ & $120.67 \pm 1.20 c$ \\
\hline M. + P. $(1000: 20)$ & $712.00 \pm 30.02 c$ & $369.33 \pm 18.70 b$ & $207.00 \pm 25.11 b$ \\
\hline M. + P. $(1000: 50)$ & $656.00 \pm 6.11 d$ & $377.67 \pm 34.72 b$ & $151.67 \pm 12.02 c$ \\
\hline Nematode only (1000 J2) & $960.67 \pm 6.36 a$ & $841.00 \pm 29.67 a$ & $704.33 \pm 27.51 a$ \\
\hline \multirow[t]{2}{*}{$\operatorname{LSD}(P=5 \%)$} & 110.6 & 65.6 & 32.7 \\
\hline & \multicolumn{3}{|c|}{ Mean numbers $\pm \mathrm{SE}$ of $P$. fimetorum mite } \\
\hline M. + P. $(1000: 10)$ & $7.00 \pm 0.58 c$ & $6.00 \pm 1.16 c$ & $6.33 \pm 0.67 c$ \\
\hline M. + P. $(1000: 20)$ & $15.67 \pm 1.45 b$ & $14.67 \pm 0.67 b$ & $13.67 \pm 0.88 b$ \\
\hline M. + P. $(1000: 50)$ & $32.33 \pm 1.45 a$ & $27.00 \pm 4.04 a$ & $34.00 \pm 1.53 a$ \\
\hline \multirow[t]{2}{*}{$\operatorname{LSD}(P=5 \%)$} & 2.1 & 1.8 & 2.5 \\
\hline & \multicolumn{3}{|c|}{ Reduction percentages of $M$. javanica juveniles } \\
\hline M. + P. $(1000: 10)$ & 14.09 & 74.75 & $82.87^{*}(57.24)$ \\
\hline M. + P. $(1000: 20)$ & 25.88 & 56.08 & $70.61^{*}(50.87)$ \\
\hline M. + P. $(1000: 50)$ & 31.71 & 55.09 & $74.47^{*}(53.77)$ \\
\hline
\end{tabular}

*Numbers between brackets presented overall reduction

Means in each column followed by the same letter(s) are not significantly different at $5 \%$ level 
Also, Imbriani and Mankau (1983) reported that the predatory mite, Lasioseius scapulatus Kennett 1958, drastically reduced the population of Aphelenchus avenae Bastian 1865. Chen et al. (2013) stated that the number of Radopholus similis (Cobb 1893) Thorne 1949 decreased by (66\%) with the predatory mite, Blattisocius dolichus (Ma 2006). While the data presented by Dmowska et al. (1997) proved that it was still premature to evaluate the effectiveness of Parasitus bituberosus Karg 1972 against rhabditid nematodes because the life table parameters did not seem to be totally convincing.

\section{Efficacy of Macrocheles muscaedomesticae feeding on Meloidogyne javanica juveniles}

Data in Table 2 indicated that there were significant differences in numbers of nematode juveniles between the treatments in which the predatory mite, $M$. muscaedomesticae, was released and control at the 3 intervals of examination. Moreover, there were significant differences in nematode population among the 3 rates of the released mite. The obtained data also indicated that there were significant differences in the numbers of $M$. muscaedomesticae mite among the 3 rates of the predator. Mortality percentages of $M$. javanica juveniles presented in Table 2 showed that the highest mortality rate $(50.83 \%)$ was recorded at the treatment of (1000 nematodes +50 mites), followed by $(48.88 \%)$ at (1000 nematodes +20 mites $)$ and then by $(47.13 \%)$ at $(1000$ nematodes +10 mites).

Obtained results are in agreements with Beaulieu and Weeks (2007) who demonstrated that macrochelid mites have a potential role as biological control agents on vermiform nematodes and organisms. Machrochelidae possess greater predatory potentials, mainly because of their ability to prey a variety of nematodes in large numbers in culture and in experimental dishes (McSorley and Wang 2009).

Moreover, Sholla Salwa and El Kady (2009) reported the feeding capacity of the cunaxid mite Neocunaxoides andrei and its feeding capability on Meloidogyne javanica under laboratory or semi-field conditions. The female of Neocunaxoides andrei consumed 177.2 juveniles (J2s) of $M$. javanica within 5 days under the laboratory conditions, and in addition, the presence of 20,40, and 60 newly emerged Neocunaxoides andrei females together with $500 \mathrm{~J} 2 \mathrm{~s}, M$. javanica, in pots cultivated with tomato seedlings 15 days old caused a reduction of 59 , 74 , and $86 \%$ of $M$. javanica, respectively.

Recently, Azevedo et al. (2019) recorded Rhabditella axei Rhabditis (Rhabditella) axei (Feng and Li, 1950) as a complementary prey of Macrocheles embersoni Azevedo, Berto, and Castilho.

\section{Efficacy of $P$. fimetorum and $M$. muscaedomesticae mites in feeding on Meloidogyne javanica juveniles}

Statistical analysis of the obtained data indicated that there were significant differences in the numbers of nematode juveniles at the 3 periods of examination between the treatment of nematode only (control) and other treatments of mites releasing (Table 3).

Statistical analysis of the obtained data indicated that there were significant differences in the numbers

Table 2 Mean numbers \pm SE of Meloidogyne javanica juveniles (M.) and M. muscaedomesticae mite (Mac.) extracted from different treatments and mortality percentages under laboratory conditions

\begin{tabular}{|c|c|c|c|}
\hline \multirow[t]{2}{*}{ Treatments } & \multicolumn{3}{|c|}{ Mean numbers \pm SE of $M$. javanica juveniles (days post-treatments) } \\
\hline & 10 & 20 & 30 \\
\hline M. + Mac. $(1000: 10)$ & $531.33 \pm 1.76 c$ & $451.67 \pm 20.88 c$ & $378.33 \pm 1.45 b$ \\
\hline M. + Mac. $(1000: 20)$ & $732.33 \pm 33.27 b$ & $378.00 \pm 10.07 d$ & $245.67 \pm 10.27 c$ \\
\hline M. + Mac. (1000:50) & $632.33 \pm 10.75 b c$ & $562.00 \pm 7.02 b$ & $121.67 \pm 3.53 d$ \\
\hline Nematode only (1000 J2) & $954.67 \pm 6.12 \mathrm{a}$ & $865.33 \pm 2.85 a$ & $745.33 \pm 5.49 a$ \\
\hline \multirow[t]{2}{*}{$\operatorname{LSD}(P=5 \%)$} & 117.8 & 70.1 & 38.4 \\
\hline & \multicolumn{3}{|c|}{ Mean numbers \pm SE of $M$. muscaedomesticae } \\
\hline M. + Mac. (1000:10) & $8.00 \pm 0.58 c$ & $7.00 \pm 0.58 c$ & $6.33 \pm 0.33 c$ \\
\hline M. + Mac. $(1000: 20)$ & $16.00 \pm 1.16 b$ & $14.33 \pm 1.20 \mathrm{~b}$ & $16.33 \pm 0.88 b$ \\
\hline M. + Mac. $(1000: 50)$ & $44.00 \pm 1.53 a$ & $40.33 \pm 2.91 a$ & $39.67 \pm 2.03 a$ \\
\hline \multirow[t]{2}{*}{ Nematode only (1000 J2) } & 4.1 & 3.2 & 2.5 \\
\hline & \multicolumn{3}{|c|}{ Reduction percentages of $M$. javanica juveniles } \\
\hline M. + Mac. (1000:10) & 44.34 & 47.80 & $49.24^{*}(47.13)$ \\
\hline M. + Mac. (1000:20) & 23.29 & 56.32 & $67.04^{*}(48.88)$ \\
\hline M. + Mac. (1000:50) & 33.76 & 35.05 & $83.68^{*}(50.83)$ \\
\hline
\end{tabular}

*Numbers between brackets presented overall reduction 
Table 3 Mean numbers \pm SE of M. javanica juveniles and P. fimetorum and M. muscaedomesticae mites at different ratios and mortality percentages under laboratory conditions

\begin{tabular}{llll}
\hline Treatments & \multicolumn{2}{l}{ Mean numbers \pm SE of M. javanica juveniles (days post-treatments) } \\
\cline { 2 - 4 } & 10 & 20 & 30 \\
\hline M. + P. + Mac. (1000:10:10) & $708.67 \pm 28.69 \mathrm{~b}$ & $583.33 \pm 9.82 \mathrm{~b}$ & $304.67 \pm 18.82 \mathrm{~b}$ \\
M. + P. + Mac. (1000:20:20) & $569.33 \pm 5.46 \mathrm{c}$ & $428.67 \pm 9.40 \mathrm{c}$ & $263.67 \pm 9.39 \mathrm{c}$ \\
M. + P. + Mac. (1000:50:50) & $319.33 \pm 62.36 \mathrm{~d}$ & $351.0 \pm 19.69 \mathrm{~d}$ & $121.67 \pm 2.03 \mathrm{~d}$ \\
Nematode only & $956.00 \pm 5.29 \mathrm{a}$ & $866.33 \pm 4.67 \mathrm{a}$ & $668.67 \pm 1.86 \mathrm{a}$ \\
LSD 5\% & 122.3 & 75.4 & 62.3 \\
& Mean numbers \pm SE of P. fimetorum and M. muscaedomesticae & $5.67 \pm 0.33 \mathrm{c}$ \\
M. + P. + Mac. (1000:10:10) & $8.67 \pm 0.33 \mathrm{c}$ & $6.67 \pm 0.33 \mathrm{~d}$ & $6.00 \pm 0.58 \mathrm{c}$ \\
& $7.67 \pm 0.33 \mathrm{c}$ & $7.00 \pm 0.58 \mathrm{~d}$ & $11.67 \pm 0.88 \mathrm{~b}$ \\
M. + P. + Mac. (1000:20:20) & $15.67 \pm 0.88 \mathrm{~b}$ & $14.00 \pm 0.58 \mathrm{c}$ & $7.67 \pm 0.88 \mathrm{c}$ \\
& $14.33 \pm 1.20 \mathrm{~b}$ & $9.00 \pm 0.58 \mathrm{~d}$ & $35.67 \pm 3.48 \mathrm{a}$ \\
M. + P. + Mac. (1000:50:50) & $40 \pm 3.06 \mathrm{a}$ & $38.67 \pm 2.19 \mathrm{~b}$ & $36.33 \pm 1.20 \mathrm{a}$ \\
LSD 5\% & $43 \pm 1.73 \mathrm{a}$ & $42.67 \pm 1.20 \mathrm{a}$ & 2.7 \\
M. + P. + Mac. (1000:10:10) & 3.1 & 2.9 & \\
M. + P. + Mac. (1000:20:20) & Reduction percentages of M. javanica juveniles \\
M. + P. + Mac. (1000:50:50) & 25.87 & 32.67 & $51.80^{*}(69.29)$ \\
\hline
\end{tabular}

*Numbers between brackets presented overall reduction

Means in each column followed by the same letters are not significantly different at $5 \%$ level

of the 2 mite species among the 3 rates of the predator (Table 3). The highest mortality percentages in nematode juveniles $(69.29 \%)$ was recorded at the treatment of (1000 nematodes +50 mite/species), followed by $(50.51 \%)$ at $(1000$ nematodes $+20 \mathrm{mite} / \mathrm{species})$ and $(37.66 \%)$ at (1000 nematodes +10 mite/species).

\section{Greenhouse experiments}

At the pot experiments in the greenhouse, there were several interactions between the population of predacious mites and nematodes under such semi-field conditions. Tomato seedlings were used during the course of the study. Statistical analysis of the obtained data revealed that there were significant differences in the numbers of nematode juveniles extracted from different treatments, as well as between the 2 periods of examination (Table 4). The highest nematode juvenile numbers were recorded at the treatment of M. muscaedomesticae mite, giving 3236 and $4308.67 \mathrm{~J} 2$ at 30 and 60 days of nematode inoculation $($ LSD $5 \%=354.2$ and 502.4, respectively, followed by the treatment with $P$. fimetorum mite, giving 2264 and 3316 $\mathrm{J} 2$ at 30 and 60 days of nematode inoculation (LSD 5\% = 354.2 and 502.4), respectively, while the lowest nematode juvenile numbers were found at $M$. muscaedomesticae + $P$. fimetorum mite treatments, giving 1752 and $2162 \mathrm{~J} 2$ at 30 and 60 days of nematode inoculation (LSD 5\% $=354.2$ and 502.4), respectively.
As for the mean numbers of mite species summarized in (Table 5), extracted from tomato soil, 30 and 60 days after planting, results show that there were significant differences in the numbers of mites, as well as between the 2 periods of examination (Table 5).

Data in Table 6 show that the highest overall mortality percentage in $M$. javanica juveniles $(57.07 \%)$ was recorded at the treatment of $P$. fimetorum and $M$. muscaedomesticae, followed by $(39.17 \%)$ at the treatment with

Table 4 Mean numbers \pm SE of M. javanica juveniles extracted from tomato soil at the treatments of 2 mite species, $P$. fimetorum and $M$. muscaedomesticae, under greenhouse conditions

\begin{tabular}{lll}
\hline Treatments & \multicolumn{2}{l}{$\begin{array}{l}\text { Mean numbers } \pm \text { SE of consumed } \\
\text { nematode (juveniles per } 2 \mathrm{~kg} \text { soil) }\end{array}$} \\
\cline { 2 - 3 } & 30 days & 60 days \\
\hline M. + P. (5000:100) & $2264 \pm 65.13 \mathrm{c}$ & $3316 \pm 161.39 \mathrm{c}$ \\
M. + Mac. (5000:100) & $3236 \pm 100.06 \mathrm{~b}$ & $4308.67 \pm 183.68 \mathrm{~b}$ \\
M. + P. + Mac. (5000:100 + 100) & $1752 \pm 102.01 \mathrm{~d}$ & $2162 \pm 35.04 \mathrm{~d}$ \\
M. javanica (control) & $4206 \pm 61.19 \mathrm{a}$ & $4889 \pm 316.84 \mathrm{a}$ \\
P. fimetorum & 0 & 0 \\
M. muscaedomesticae & 0 & 0 \\
Check & 0 & 0 \\
LSD 5\% & 354.2 & 502.4 \\
\hline
\end{tabular}

Means in each column followed by the same letter are not significantly different at $5 \%$ level 
Table 5 Mean numbers \pm SE of the mite species, $P$. fimetorum and $M$. muscaedomesticae, when fed on root knot nematode, $M$. javanica juveniles, extracted from tomato soil under greenhouse conditions

\begin{tabular}{lll}
\hline Treatments & \multicolumn{2}{l}{$\begin{array}{l}\text { Mean no. of mites } \pm \text { SE/2 kg soil after } \\
\text { two intervals }\end{array}$} \\
\cline { 2 - 3 } 30 days & 60 days \\
\hline M. + P. (5000:100) & $86.67 \pm 0.88 \mathrm{a}$ & $89.00 \pm 4.00 \mathrm{a}$ \\
M. + Mac. (5000:100) & $59.00 \pm 1.16 \mathrm{c}$ & $62.67 \pm 6.49 \mathrm{~b}$ \\
M. + P. + Mac. (5000:100:100) & $73.67 \pm 4.98 \mathrm{~b}$ & $93.00 \pm 2.52 \mathrm{a}$ \\
M. javanica & $51.33 \pm 4.63 \mathrm{~d}$ & $62.00 \pm 4.36 \mathrm{~b}$ \\
P. fimetorum 100 & 0 & 0 \\
M. muscaedomesticae 100 & $57.33 \pm 1.76 \mathrm{~cd}$ & $39.33 \pm 0.88 \mathrm{c}$ \\
Check & 0 & $32.00 \pm 1.16 \mathrm{~d}$ \\
LSD 5\% & 6.5 & 0 \\
\hline
\end{tabular}

Means in each column followed by the same letter(s) are not significantly different at $5 \%$ level

P. fimetorum, while the treatment of $M$. muscaedomesticae recorded only (17.47\%).

Results in Table 7 show the average numbers of root knot nematode galls in tomato roots (60 days) at different treatments of predatory mites in comparison with control. The statistical analysis of the data indicated that there were significant differences in gall numbers among treatments.

Results in Table 7 indicated that the highest decrease percentage in root knot nematode galls $(56.3 \%)$ was recorded at the treatment of $P$. fimetorum and $M$. muscaedomesticae mites, followed by P. fimetorum (44.3\%), while the least (30\%) was obtained at the treatment of M. muscaedomesticae. The obtained results are in agreements with (McSorley and Wang 2009) who reported that bioagent treatments reduced numbers of $M$. javanica was greater in tomato soil, especially mites, collembola. Also, Manwaring et al. (2015) stated that Macrocheles matrius and Onychiurus armatus (collembolan) are known to feed on nematodes and other plant parasites and decrease the root knot nematode galls and egg masses.

Table 6 Reduction percentages of M javanica juveniles in tomato soil, consumed by the predatory mites, P. fimetorum and M. muscaedomesticae, at different rates and periods under greenhouse conditions

\begin{tabular}{llll}
\hline Treatments & \multicolumn{2}{l}{ Reduction (\%) } & \multirow{2}{*}{ Overall reduction (\%) } \\
\cline { 2 - 3 } & 30 days & 60 days & \\
\hline M. j. + P. f. (5000:100) & 46.17 & 32.17 & 39.17 \\
M. j. + M. m. (5000:100) & 23.06 & 11.87 & 17.47 \\
$\begin{array}{llll}\text { M. j. + P. f. }+ \text { M. m. } \\
\begin{array}{l}\text { (5000:100:100) } \\
\hline\end{array}\end{array}$ & 58.35 & 55.78 & 57.07 \\
\hline
\end{tabular}

Table 7 Average numbers of root knot galls in tomato roots (60 days) at different treatments of predatory mites in comparison with control treatment

\begin{tabular}{lll}
\hline Treatments & $\begin{array}{l}\text { Average numbers of } \\
\text { root knot galls per root }\end{array}$ & Reduction percentages (\%) \\
\hline M. + P. (5000:100) & $9.3 \mathrm{C}$ & 44.3 \\
M. + M. (5000:100) & $11.7 \mathrm{~b}$ & 30.0 \\
$\begin{array}{l}\text { M. + P. + M. m. } \\
\text { (5000:100:100) }\end{array}$ & $7.3 \mathrm{C}$ & 56.3 \\
$\begin{array}{l}\text { M. javanica } \\
\text { (control) }\end{array}$ & $16.7 \mathrm{a}$ & - \\
LSD 5\% & 2.2 & \\
\hline
\end{tabular}

Means in the column followed by the same letter are not significantly different at $5 \%$ level

\section{Conclusion}

Using combined treatment of two predatory mites, $P$. fimetorum and M. muscaedomesticae, showed a high potential in reducing the number of $M$. javanica than using each predatory mite alone. Moreover, the results confirmed that parasitic nematodes can be safely controlled by predacious mites in an attempt to reduce depending upon chemical pesticides.

\section{Abbreviations \\ P.: Parasitus fimetorum; Mac:: Macrocheles muscaedomesticae; M.: Meloidogyne javanica}

\section{Authors' contributions}

The author collected and identified predacious mites and nematode and wrote the manuscript. The author read and approved the final manuscript.

\section{Funding}

No funding

\section{Availability of data and materials}

All data generated and/or analyzed during the present study are available in the manuscript, and the corresponding author has no objection to the availability of data and materials.

\section{Ethics approval and consent to participate}

Not applicable. The study was conducted on mites and nematode species that are abundant in the environment and does not require ethical approval.

\section{Consent for publication}

The author agrees to publish this paper. The data has not been published in completely or in part in other journal.

\section{Competing interests}

The author declares that he has no competing interests.

Received: 5 January 2020 Accepted: 16 March 2020

Published online: 23 March 2020

\footnotetext{
References

Abbott WS (1925) A method of computing the effectiveness of an insecticide. J Econ Entomol 18:265-267

Al-Rehiayni SM, Fouly AH (2005) Cosmolaelaps simplex (Berlese), a polyphagous predatory mite feeding on root-knot nematode Meloidogyne javanica and citrus nematode Tylenchulus semipenetrans. Pakistan J Biol Sci. 8:168-174

Azevedo LH, Leite LG, Chacon-Orozco JG, Moreira MFP, Ferreira MP, GonzálezCano LM, Borges V, Rueda-Ramírez D, Moraes GJ, Palevsky E (2019) Free living nematodes as alternative prey for soil predatory mites: an
} 
interdisciplinary case study of conservation biological control. Bio Con 132: 128-134

Beaulieu F, Weeks AR (2007) Free-living mesostigmatic mites in Australia: their roles in biological control and bioindication. Aust J Exp Agr 47:460-478

Carrillo D, de Moraes G J, Pena JE (Eds.) (2015) Prospects for biological control of plant feeding mites and other harmful organisms. Progress in Biological Control 19; Cham: Springer. xiv + 328 pp.

Chen YL, Xu C, Xu X, Xie H, Zhang BX, Qin HG, Zhou WQ, Des LI (2013) Evaluation of predation abilities of Blattisocius dolichus (Acari: Blattisociidae) on a plant parasitic nematode, Radopholus similis (Tylenchida: Pratylenchidae). Exp Appl Acarol 60(3):289-298

CoStat version 6.400 Copyright $\odot$ (1998-2008) Cohort Software.798 Lighthouse Ave. PMB 320, Monterey, CA, 93940, USA.

Dmowska E, Dmoch J, llieva K (1997) Early interaction of the bacterivorous nematodes Rhabditis cucumeris and the edible fungus Agaricus bisporus in relation to time and quality of nematode inoculation. Int J Mushroom Sci 2:15-23

El-Hady Mona M, El-Naggar HI (2001) Possibility of the control of the root-knot nematode Meloidogyne incognita on sunflower plants by certain predaceous mites. J Agric Sci Mansoura Univ 26(4):2391-2395

El-Khateeb H M (1998) Life tables of some predacious mites and their importance in biological control. Ph D Thesis Fac Agric Cairo Univ:107 - 109.

Fouly AH (1996) Effects of prey mites and pollen on the biology and life tables of Proprioseiopsis asetus, Acari: Phtoseiidae. Egypt J Biol P Control 6(1):13-19

Imbriani JL, Mankau R (1983) Studies on Lasioseius scapulatus, a mesostigmatid mite predaceous on nematodes. J Nematol 15:523-528

Kazemi S, Arjomandi E, Ahangaran Y (2013) A review of the Iranian Parasitidae (Acari: Mesostigmata). Pers J Acarol 2:159-180

Kerry BR, Hominick WM (2002) Biological control. Taylor \& Francis, London

Lindquist EE, Ainscough BD, Clulow FV, Funk RC, Marshall VG, Nesbit HH, Oconnor BM, Smith IM, Wilkinson PR (1979) Acari: Mem. Ent Soc Can 108: 252-290

Maareg MF, Gohar IMA, Rady GH (2005) Predatory behavior of some soil mites towards root-knot nematode, Meloidogyne incognita infecting sugar beet crop. Egypt J Agric Res 83(2):527-536

Manwaring M, Walter D, Stirling GR (2015) Microarthropods as predators of nematode pests in sugarcane soils: literature review and preliminary studies. Proc Aust Soc Sugar Cane Technol 37:205-213

McSorley R, Wang KH (2009) Possibilities for biological control of root-knot nematodes by natural predators in Florida soils. Proc Fla State Hort Soc 122:421-425

Mostafa AM, Abdel-Rahman Amina M, Yassin EMA, Saber Rania H (2013) Effect of different food on development, reproduction and survival of Uroobovilla krantzi Zaher and Afifi (Acarina: Uropodidae). Egypt J Agric Res 91(3):913-923

Mostafa FA, Fouly AH, El-Sherif AG (1997) Biological control of Meloidogyne javanica infecting tomato by the predaceous mite Lasiosieus dentatus. Egypt J Agronematol 1(1):113-120

Palacios SM, Bertoni A, Rossi Y, Santander R, Urzúa A (2009) Efficacy of essential oils from edible plants as insecticides against the house fly, Musca domestica L. Molecules 14:1938-1947

Sholla Salwa M E (2000) Taxonomical and biological studies on some predacious Actinedid mites. MSc Thesis Fac Agric Ain Shams Univ 167 pp.

Sholla Salwa ME, El Kady GA (2009) The Cunaxid Mite Neocunaxoides andrei (B. \& $\mathrm{H}$.) as a biological control agent of the root-knot nematode Meloidogyne javanica Chitwood. Acarines 3:55-58

Taha HA, El-Naggar ME, Abou-El-Naga MM, Soliman SM (1988) Effect of different prey species on the development and fecundity of the predacious mite, Neocunaxoides andrei (B\&H), (Acari: Cunaxidae). Agric Res Revi 66(1):129-135

Van de Bund CF (1972) Some observations on predatory action of mites on nematodes. Zeszyty Problemouve postepow Nauk Rolniczych 129:104-110

Walter DE, Kaplan DT (1991) Observations on Coloscerius simplex (Acarina: Prostigmata), a predatory mite that colonizes greenhouse cultures of rootknot nematode (Meloilogyne spp.) and a review of feeding behavior in the Cunaxidae. Exper Appl Acarol 12(1-2):47-59

Wilkins RM, Khalequzzaman M (1993) Environmental interactions of pesticides: synergism of permethrin by simazine against housefly. Proc Brighton crop Protect Conf 3B-7:157-162

Yeates GW, Wardle DA (1996) Nematodes as predators and prey: relationships to biological control and soil processes. Pedobiologia 40:43-50

\section{Publisher's Note}

Springer Nature remains neutral with regard to jurisdictional claims in published maps and institutional affiliations.

\section{Submit your manuscript to a SpringerOpen ${ }^{\circ}$ journal and benefit from:}

- Convenient online submission

- Rigorous peer review

- Open access: articles freely available online

High visibility within the field

- Retaining the copyright to your article

Submit your next manuscript at $\boldsymbol{\nabla}$ springeropen.com 